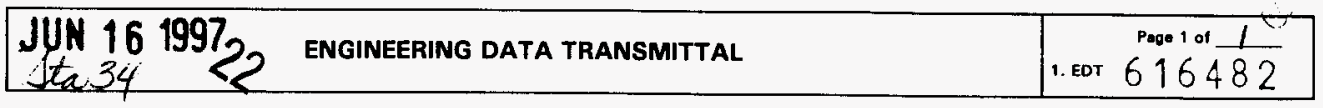

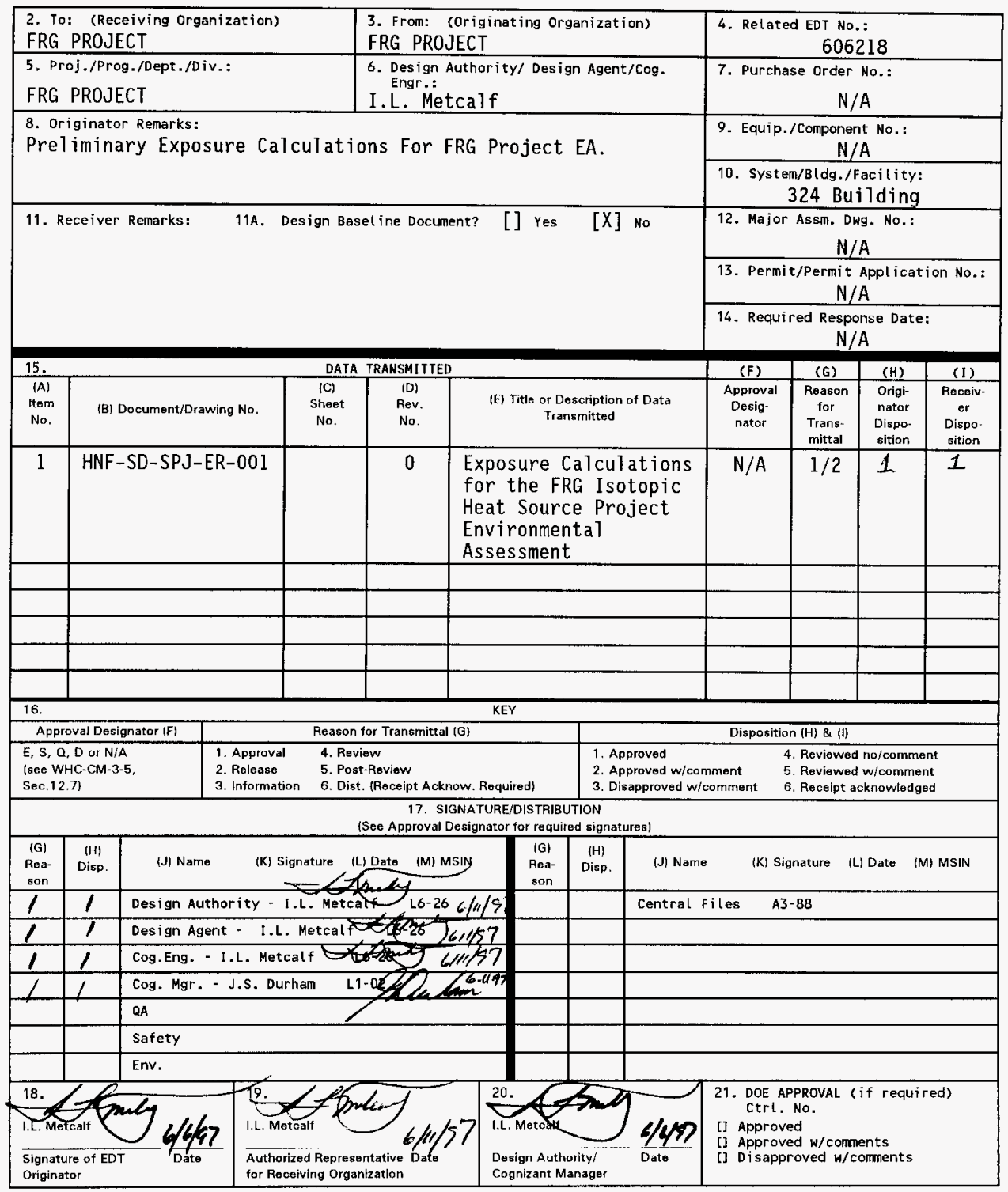

BD-7400-172-2 (05/96) GEF097 


\section{EXPOSURE CALCULATIONS FOR THE FRG ISOTOPIC HEAT SOURCE PROJECT ENVIRONMENTAL ASSESSMENT}

\section{L. Metcalf}

B\&W Hanford Company, Richland, WA 99352

U.S. Department of Energy Contract DE-AC06-96RL13200

EDT/ECN: 616482

Org Code: 19120

B\&R Code: 600302000
UC: 2050

Charge Code: TF $1 \mathrm{C} 1$

Total Pages: 8

Key Words: EA, FRG, Dose Calculations, 324 Building, Isotopic Heat Source, CWC

Abstract: The report documents the maximum exposure for transfer of the Federal Republic of Germany (FRG) Isotopic Heat Sources from the 324 Building and placed in interim storage at the Central Waste Complex (CWC). These results are to be reported in the Environmental Assessment DOE-EA-1211.

TRADEMARK DISCLAIMER. Reference herein to any specific commercial product, process, or service by trade name, trademark, manufacturer, or otherwise, does not necessarily constitute or imply its endorsement, recommendation, or favoring by the United States Government or any agency thereof or its contractors or subcontractors.

Printed in the United States of America. To obtain copies of this document, contact: Document Control Services, P.O. Box 950, Mailstop H6-08, Richland WA 99352, Phone (509) 372-2420; Fax (509) 376-4989.

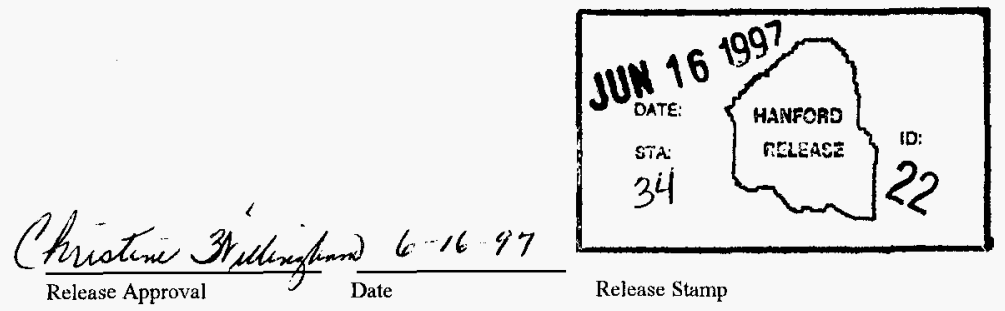

\section{Approved for Public Release}




\section{EXPOSURE CALCULATION FOR THE FRG ISOTOPIC HEAT SOURCE PROJECT ENVIRONMENTAL ASSESSMENT}

\subsection{INTRODUCTION/BACKGROUND}

As part of a bilateral agreement between the Federal Ministry for Research and Technology of the Federal Republic of Germany (FRG) and the DOE, Pacific Northwest National Laboratory (PNNL) developed processes for the treatment and immobilization of high-level radioactive waste. One element of this bilateral agreement was the production of sealed isotopic heat sources. During the mid-1980s, 30 sealed isotopic heat sources were manufactured during three production runs in the 300 Area, 324 Building B-Cell (PNL 1989). Two production demonstration canisters and two instrumented canisters also were produced. The 34 stainless steel canisters were filled with radioactive borosilicate glass. The sources contain a total of approximately 8.3 million curies consisting predominately of cesium-137 and strontium- 90 with trace amounts of transuranic contamination. Currently, the sources are stored in A-Cell of the 324 Building.

An Environmental Assessment (EA) is being prepared to determine the environmental impact of relocating these sources to the central Waste Complex (CWC). The sources would be placed in a shipping/storage cask and transported by road or rail/road combination and placed at an interim storage site at the $\mathrm{CWC}$. The purpose of this document is to determine the maximum personnel exposure for input to the EA.

The proposed action involves: the construction of a storage site located within the Central Waste Complex (CWC) in the 200 West Area and relocation of the isotopic heat sources from the 324 Building to the storage site, including handling, transportation, and storage. The CWC is committed to waste management activities by treating and storing mixed and/or radioactive waste. The storage site would allow monitoring, surveillance, maintenance, and retrieval capability until a national repository is established for this waste type. At that time, the waste would be relocated to a national repository.

The proposed action would include the construction of a reinforced concrete storage pad near the intersection of 16th Avenue and Dayton Street, adjoining the existing Alkali Metals Storage Pad. The storage pad would have the approximate dimensions of 9.1 meters ( 30 feet) by 32 meters (105 feet) with a metal roof over the storage pad for weather protection.

Two types of previously constructed transportation/storage casks (hereinafter referred to as "casks") will be used in the proposed action and have been provided by the German Government. The casks would provide containment of the payload. Assurance of competent performance of the cask designs has been established both by analysis and by testing. Assurance of the CASTOR cask performance is documented in: "Safety Analysis Report for Packaging (Onsite) CASTOR GSF Cask" (RFSH 1997b). Assurance of the GNS cask performance is documented in: "Safety Analysis Report for Packaging (Onsite) for the GNS-12 Packaging" (RFSH 1997a). 


\title{
HNF-SD-SPJ-ER-001
}

\author{
Rev. 0
}

Loading of the isotopic heat sources into these casks using remotely operated cranes would occur in the 324 Building radiochemical engineering cells (REC). The REC is a shielded facility equipped for remote handling of highly radioactive materials. Entry into the shielded hot cells is through a shielded airlock (Figure 1).

Transportation of the loaded casks would use both rail and truck or truck only. Up to eight shipments would be required to relocate the isotopic heat sources from the 300 Area to the 200 West Area.

Transportation by rail would occur from the 324 Building to the 200 West Area laydown pad. The laydown pad would be approximately 0.8 kilometers $(1 / 2 \mathrm{mile})$ from the storage site at CWC. The casks would be loaded on a rail car at the 324 Building. All casks would be transported over a railroad system within the Hanford Site boundary. During transportation, the railroad system crosses roadways accessible to the general public or site employees at two locations. To preclude potential radiation exposure to the general public or site employees during transportation, the railroad crossings would be closed by Hanford Patrol when a train approached the crossing. Upon reaching the laydown pad, the casks would be off-loaded by a portable crane onto a truck and transported 0.8 kilometer $(1 / 2$ mile $)$ to the storage site. On reaching the storage site, a portable crane would off-load the cask onto the storage site. Total transportation time for a single cask is expected to take approximately 3.5 hours.

Transportation by truck only would occur directly from the 324 Building to the storage site. The casks would be loaded on a truck in the 324 Building. All casks would be transported over roadways located within the Hanford Site boundary. To preclude potential radiation exposure to the general public or site employees during transportation, the roadways would be restricted by Hanford Patrol. On reaching the storage site, a portable crane would off-load the cask onto the storage site. Total transportation time for a single cask is expected to take approximately 2.0 hours. 
HNF-SD-SPJ-ER-001

Rev. 0

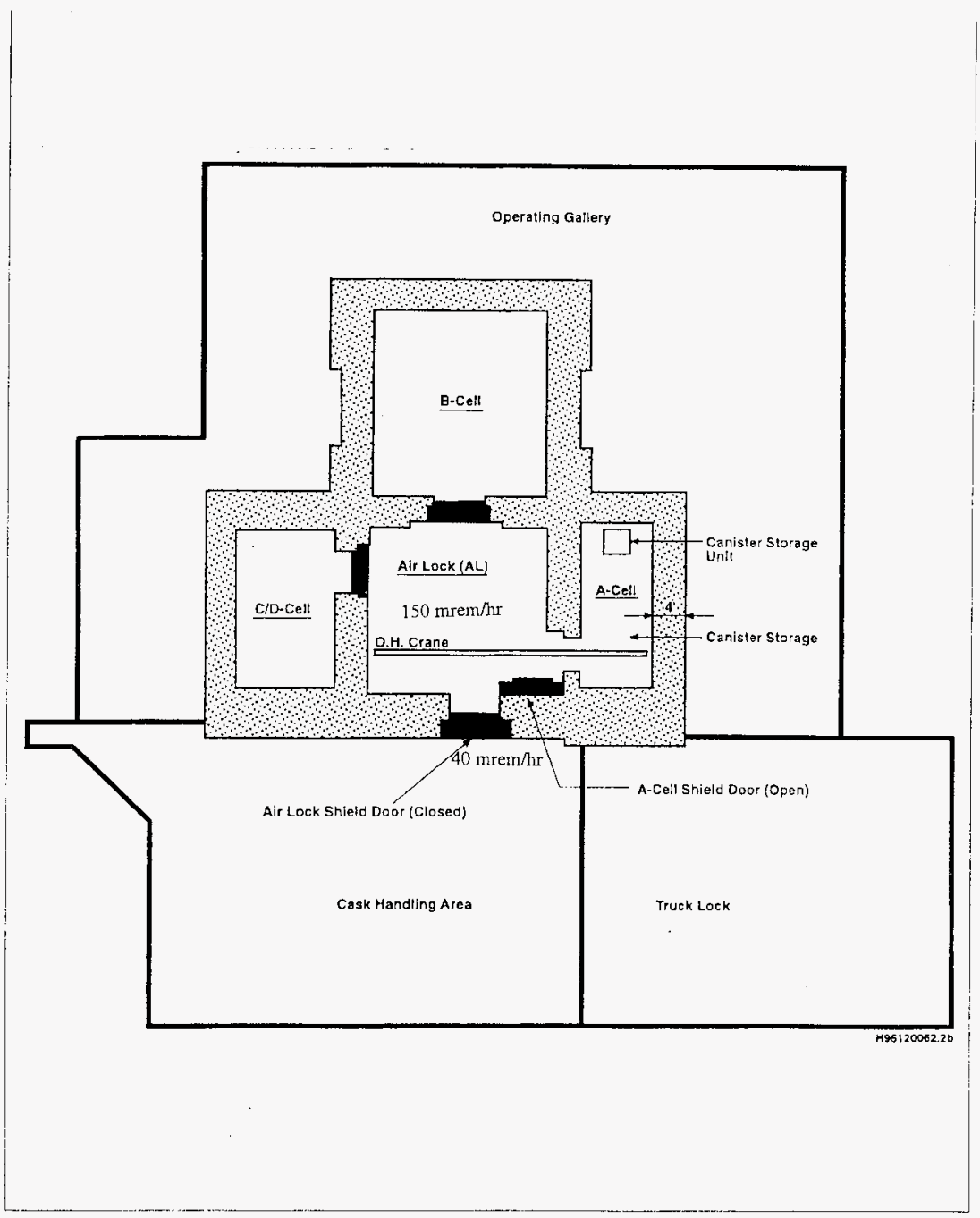

Figure 1. 324 Building Radiochemical Engineering Cells. 


\section{HNF-SD-SPJ-ER-001}

Rev. 0

\subsection{RADIATION EXPOSURE AND THE CONSEQUENCES}

Worker exposure to radiation that would result from the proposed action was estimated (RFSH 1997a, RFSH 1997b) to determine the dose rates from loaded casks and work durations for similar types of activities currently conducted at the Hanford Site. For direct radiation exposure, assumptions were made regarding the number of workers that would be involved in the proposed action and the potential radiological dose that could be received. Projected health effects in terms of latent cancer fatalities (LCF) for the proposed action were calculated based on the potential radiological dose.

The loading of the isotopic heat sources into the casks will be conducted remotely within the 324 Building REC (Figure 1). The first major activity in preparation for loading of a cask is to install the cask transfer rails in the air lock. This is a one time operation. It will require one operator in the air lock with a background of approximately 0.15 rem per hour for one hour and two support personnel at the door threshold with a background of approximately 0.04 rem per hour for up to one hour. ALARA principles will be utilized to maximum extent possible to reduce exposure. The total dose for the three workers is 0.23 person-rem (maximum).

The cask airlock is only opened briefly for installation of the threshold rails and to push the cask into position using the remote pusher tool. This will require up to two operators at the threshold ( 0.04 rem per hour) for up to 15 minutes. Entry into the airlock is not required. The total dose to the two operators for the eight transfers is 0.16 person-rem (maximum).

With the cask in position, the threshold rails removed, the air lock shield door is closed, the A-Cell shield door opened, and the canisters transferred from A-Cell and loaded in the cask remotely. After a cask is loaded, the cask lid is placed on the cask, the A-Cell shield door closed, an airlock shield door opened, and the cask and cart pulled to the door opening using a tugger cable. Entry into the airlock is not required.

At the door entrance, one health physics technician and two craft persons will prepare the cask for removal from the airlock to the cask handling area. Each worker is assumed to receive a radiation dose of 0.07 rem per hour (maximum) at the cask surface for the two GNS Casks and 0.04 rem per hour (maximum) at the cask surface for the six CASTOR casks plus the background at the door opening of approximately 0.04 rem per hour. An estimated 30 minutes will be required. The total dose to the three workers for this operation will be 1.05 person-rem (maximum).

The cask is then moved to the cask handling area, where personnel consisting of two crafts persons and one health physics technician will be required to install the lid closure bolts. These individuals will be properly attired as identified by a radiation work permit (RWP) and will comply with as low as reasonably achievable (ALARA) principles. Each worker is assumed to receive a radiation dose of 0.07 rem per hour (maximum) at the cask surface for the two GNS casks and 0.04 rem per hour (maximum) at the cask surface for the six CASTOR casks. An estimated one hour will be required to complete the bolt installation. After the lid closure bolts are tightened, a leak-check 


\section{HNF-SD-SPJ-ER-001 \\ Rev. 0}

technician will be required to verify the integrity of the cask seal by performing a leak test. This individual will be properly attired as identified by the RWP and will comply with ALARA principles. It is assumed that the technician will receive a radiation dose of 0.07 rem per hour (maximum) at the cask surface for the two GNS casks and 0.04 rem per hour (maximum) at the cask surface for the six CASTOR casks. An estimated one hour will be required to complete the leak test. The total dose to the four workers for the cask loading operations and leak testing will be 1.5 person-rem (maximum).

Four personnel will be involved in loading and tying down the cask to the rail car or truck at the 324 Building for transport of the casks to the storage site. Personnel could consist of two riggers, one health physics technician, and one inspector. Personnel will be properly attired as identified in the RWP and will comply with ALARA principles. Each worker is assumed to receive a radiation dose of 0.07 rem per hour (maximum) at the cask surface for the two GNS casks and 0.04 rem per hour (maximum) at the cask surface for the six CASTOR casks during tying down operations. An estimated one hour will be required to complete the tie down operation, which will result in a total dose to workers of 1.5 person-rem (maximum).

For rail transport, it is estimated that there will not be any exposure to workers during transport. For off loading the casks onto the truck at the lay down pad, personnel are assumed to consist of two riggers, one health physics technician, and one inspector. Personnel will be properly attired as identified in the RWP and will comply with ALARA principles. Each worker is assumed to receive a radiation dose of 0.07 rem per hour (maximum) at the cask surface for the two GNS casks and 0.04 rem per hour (maximum) at the cask surface for the six CASTOR casks during transfer operations. An estimated two hours will be required to complete the transfer from the rail car to the truck. During transport from the laydown pad to the storage site, a driver and one other occupant in the cab of the truck are assumed to be the only individuals in close proximity to the shipping cask. Each is assumed to be exposed to a dose rate of 0.002 rem per hour (maximum) during the move from the railroad spur to the storage site in the 200 West Area. The maximum travel time from the laydown pad to the storage location is estimated at 30 minutes. The total dose to workers for this method of transportation is 3.0 person-rem (maximum).

For the truck-only scenario, the maximum transport time between the 324 Building and the storage site is estimated to be two hours. During transport from the 324 Building to the storage site, a driver and one other occupant in the cab of the truck are assumed to be the only individuals in close proximity to the shipping cask. Each is assumed to be exposed to a dose rate of 0.002 rem per hour (maximum) during the move from the 324 Building to the storage site in the 200 West Area. The total dose to the driver and occupant during transportation for all eight loaded casks is estimated to be 0.06 person-rem (maximum).

Four personnel will be involved in unloading the casks onto the storage site. Personnel are assumed to consist of two riggers, one health physics technician, and one inspector. Personnel will be properly attired as identified in the RWP and will comply with ALARA principles. Each 


\section{HNF-SD-SPJ-ER-001}

Rev. 0

worker is assumed to be exposed to a radiation dose of 0.07 rem per hour (maximum) at the cask surface for the two GNS casks and 0.04 rem per hour (maximum) at the cask surface for the six CASTOR casks during tying down operations. An estimated one hour will be required to complete the unloading operation, which will result in a total dose to workers of 1.5 person-rem (maximum).

The worker-cumulative dose received for transport of the eight loaded casks by railroad and truck is calculated to be about 8.9 person-rem (maximum). While different personnel may be used for the different transfer operations, for conservatism it is assumed that the same personnel are used. Applying the International Commission on Radiological Protection (ICRP) coefficient for low dose, low dose-rate whole body irradiation of $0.0004 \mathrm{LCF}$ per person-rem effective dose equivalent for a worker population, a projected $0.0036 \mathrm{LCF}$ is calculated or a chance of about 1 in 280 . Based on this calculation, no LCF would be expected.

The worker-cumulative dose for transport of the eight loaded casks by truck is calculated to be about 6.0 person-rem (maximum). While different personnel may be used for the different transfer operations, for conservatism it is assumed that the same personnel used. Applying the ICRP coefficient for low dose, low dose-rate whole body irradiation of 0.0004 LCF per person-rem effective dose equivalent for a worker population, a projected 0.0024 LCF is calculated or a chance of about 1 in 416 . Based on this calculation, no LCF would be expected. 


\section{HNF-SD-SPJ-ER-001 \\ Rev. 0}

\subsection{REFERENCES}

RFSH, 1997a, Safety Analysis Report for Packaging (Onsite) for the GNS-12 Packaging, HNF-SD-TP-SARP-022, Rust Federal Services Hanford, Richland, Washington.

RFSH, 1997b, Safety Analysis Report for Packaging (Onsite) CASTOR GSF Cask, HNF-SD-TP-SARP-021, Rust Federal Services Hanford, Richland, Washington. 